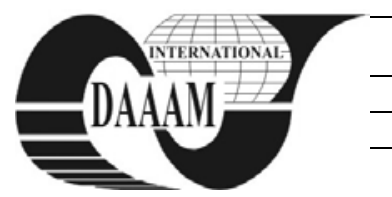

\title{
MATHEMATICAL MODELLING OF THE SPRAY DRYING TECHNOLOGICAL PROCESS
}

\section{ORLOVSKY, I[mrich]; ZAJAC, J[ozef]; MONKA, P[eter]; MICHALIK, P[eter] \& SIMKULET, V[ladimir]}

\begin{abstract}
Paper describes procedure of creating the mathematical model for spraying kiln. On the base of this model there was balance equation generated that served for definition of observed dependency. This dependency was used for identification of parameters affecting the quality of ceramic granulate that is formed after spraying of emulsion in spraying kiln.
\end{abstract}

Key words: drying, humidity, granulate, mathematical mode

\section{INTRODUCTION}

Drying process presents main production part of products made of silicon carbide. That is the reason for having sufficient attention for understanding of this process from the viewpoint of possibility to obtain optimal attributes of ceramic granulates. Main parameter of whole process that is monitored during drying process itself is moisture of granulate that directly affects its quality. For creation of mathematical model the real drying process was used from Ceramtec s.r.o, Czech Republic. Experimental measurements were realized with spraying kiln Škoda 100F. On the base of achieved information and realized experiments tha model was created, that describes and defines balance equation for expression of searched dependency.

\section{MATHEMATICAL MODEL OF THE DISPENSE KILN}

Function of mathematical model of kiln is to theoretically describe inputs and outputs, to find the relations between them and to derivate searched dependence of granulate moisture on moisture of drying gas on kiln output. At the same time this mathematical model allows theoretical description of dependences of output values and their impact to input parameters.

Kiln is a device, where the material is on purpose dried after leading in and out the drying gas. Drying gas is prepared by heating of the air sucked from environment. The heating is often obtained from incineration of combustibles. Drying gas then consist of air and combustion products. To main parameters of drying gas belong temperature $\boldsymbol{t}$, relative moisture $\boldsymbol{\varphi}$, absolute moisture $\boldsymbol{Y}$ and enthalpy $\boldsymbol{i}$. Air form the environment with parameters $\boldsymbol{t}_{\boldsymbol{0}}, \boldsymbol{\varphi}_{\boldsymbol{0}}, \boldsymbol{Y}_{\boldsymbol{o}}, \boldsymbol{i}_{\boldsymbol{o}}$ is sucked into the combustion chamber. After heating the mixture of drying gas (air + combustion products) enters the kiln with parameters $\boldsymbol{t}_{\mathbf{1}}$, $\varphi_{1}, Y_{1}, i_{1}$. After entering the kiln the gas comes to contact with dried material and removes the moisture out of it. That changes on the output its parameters to $\boldsymbol{t}_{2}, \boldsymbol{\varphi}_{2}, \boldsymbol{Y}_{2}, \boldsymbol{i}_{2}$.

Gas used as drying environment is the mixture of dry air and water steam, so called moist air. Physical quantities of moist air are graphically presented in moist air diagram. Volume of water steam $\boldsymbol{Y}$ (absolute moisture) in the air can not be variable. Water steam are in overheated state, at the line of fullness (full state) the steam is rich. Enthalpy is combined form enthalpy of dry air and enthalpy of water steam.

\subsection{Drying gas coming into the kiln}

Drying gas, in this case the mixture of combustion products and air sucked from environment is brought into the kiln with required temperature. Heat that is necessary for drying comes from heat source. To main parameters of drying gas belong:

- temperature $\left(t_{1}\right)\left[{ }^{\circ} \mathrm{C}\right]$,

- mass flow $\left(\dot{m}_{s p}\right)\left[\mathrm{kg} \cdot \mathrm{s}^{-1}\right]$,

- absolute moisture $\left(Y_{1}\right)\left[\mathrm{kg}^{\mathrm{kg}} \mathrm{kg}^{-1}\right]$,

- relative moisture $\left(\varphi_{1}\right)[\%]$,

- enthalpy $\left(i_{1}\right)\left[\mathrm{J}_{\mathrm{kg}} \mathrm{kg}^{-1}\right]$

\subsection{Emulsion}

Emulsion is the mixture of water and solid, that is brought into the kiln where it is sprayed over by nozzle. Because of flowing of drying gas, the water is vaporized from the mixture that is taken out of the kiln together with drying gas. To main parameters of emulsion belong:

\section{Water}

- water temperature $\left(t_{v 1}\right)\left[{ }^{\circ} \mathrm{C}\right]$,

- water mass flow $\left(\dot{m}_{v 1}\right)\left[\mathrm{kg} . \mathrm{s}^{-1}\right]$,

- mensural moisture $\left(u_{1}\right)\left[\mathrm{kg} \cdot \mathrm{kg}^{-1}\right]$,

- specific thermal capacity of water $\left(c_{v}\right)\left[\mathrm{J} \cdot \mathrm{kg}^{-1} \cdot \mathrm{K}^{-1}\right]$

Solid

- $\quad$ solid temperature $\left(t_{s 1}\right)\left[{ }^{\circ} \mathrm{C}\right]$,

- solid mass flow $\left(\dot{m}_{S}\right)\left[\mathrm{kg} . \mathrm{s}^{-1}\right]$,

- mensural moisture $\left(u_{1}\right)\left[\mathrm{kg} \cdot \mathrm{kg}^{-1}\right]$,

- specific thermal capacity of solid $\left(c_{s 1}\right)\left[\mathrm{J} \mathrm{kg}^{-1} \cdot \mathrm{K}^{-1}\right]$,

\subsection{Drying gas coming out of the kiln}

Drying gas flows from the kiln together with certain volume of granulate. This granulate falls after going through the cyclone into the collecting container and is added again into prepared emulsion. Combustion products flow to smokestack. Main parameters:

- Temperature $\left(t_{2}\right)\left[{ }^{\circ} \mathrm{C}\right]$,

- Mass flow $\left(\dot{m}_{s p}\right)\left[\mathrm{kg} \cdot \mathrm{s}^{-1}\right]$,

- Absolute moisture $\left(Y_{2}\right)\left[\mathrm{kg}^{\mathrm{kg}} \mathrm{kg}^{-1}\right]$,

- Relative moisture $\left(\varphi_{2}\right)[\%]$,

- Enthalpy $\left(i_{2}\right)\left[\mathrm{J}_{\mathrm{kg}} \mathrm{kg}^{-1}\right]$,

\subsection{Granulate}

Dried granulated of requested moisture falls from drying tower onto the conveyor, from where is after going through vibration screen stored in the bin. Its moisture is the main indicator of its qualitative parameters and has significant influence to further use. Main parameters:

- granulate temperature $\left(\mathrm{t}_{\mathrm{s} 2}\right)\left[{ }^{\circ} \mathrm{C}\right]$,

- granulate mass flow $\left(\dot{m}_{s}\right)\left[\mathrm{kg} \cdot \mathrm{s}^{-1}\right]$,

- mensural moisture $\left(u_{2}\right)\left[\mathrm{kg} \cdot \mathrm{kg}^{-1}\right]$,

- specific thermal capacity of granulate $\left(c_{\mathrm{s} 2}\right)\left[\mathrm{J}_{\mathrm{kg}} \mathrm{kg}^{-1} \cdot \mathrm{K}^{-1}\right]$ 


\section{CREATION OF BALANCE EQUATION}

On the base of these incomes and outcomes there were balance equation created. After comparison of thermal flows on input and output, the balance equation has the form:

$m_{s p} \cdot i_{1}+\dot{m}_{v 1} \cdot c_{v 1} \cdot t_{v 1}+\dot{m}_{s} \cdot c_{s 1} \cdot t_{s 1}=m_{s p} \cdot i_{2}+\dot{m}_{s} \cdot c_{s 2} \cdot t_{s 2}$

Where:

$\dot{m}_{s p}$ - mass flow of drying gas on kiln input $\left[\mathrm{kg} \cdot \mathrm{s}^{-1}\right]$

$i_{1} \quad$ - specific enthalpy of drying gas on kiln input $\left[\mathrm{J}^{\mathrm{kg}} \mathrm{kg}^{-1}\right]$

$\dot{m}_{v 1}$ - mass flow of water on kiln input $\left[\mathrm{kg} . \mathrm{s}^{-1}\right]$

$c_{v 1}$ - specific thermal capacity of water $\left[\mathrm{J} \cdot \mathrm{kg}^{-1} \cdot \mathrm{K}^{-1}\right]$

$t_{v 1}$ - temperature of water on kiln input [ $\left.{ }^{\circ} \mathrm{C}\right]$

$\dot{m}_{s}$ - mass flow of solid on kiln input [kg.s ${ }^{-1}$ ]

$c_{s 1}$ - specific thermal capacity of solid on input $\left[\mathrm{J} \mathrm{kg}^{-1} \cdot \mathrm{K}^{-1}\right]$

$t_{s 1}$ - temperature of solid on kiln input $\left[{ }^{\circ} \mathrm{C}\right]$

$i_{2}$ - specific enthalpy of drying gas on kiln output $\left[\mathrm{J}^{\mathrm{kg}} \mathrm{kg}^{-1}\right]$

$c_{\mathrm{s} 2}$ - specific thermal capacity of granulate on output $\left[\mathrm{J} \mathrm{kg}^{-1} \cdot \mathrm{K}^{-1}\right]$

$\mathrm{t}_{\mathrm{s} 2}$ - temperature of solid on output $\left[{ }^{\circ} \mathrm{C}\right]$

Product $m_{s p} . i_{1}$ presents thermal flow of drying gas on kiln input per time unit. Emulsion values express the parameters of water and solid. Thermal flow of water is expressed by product of mass flow of water, specific thermal capacity of water and temperature of solid $m_{s} \cdot c_{s 1} \cdot t_{s 1}$. Because of theoretical way of drying, the mass flow of solid $\dot{m}_{s}$ does not change. It only changes its specific thermal capacity and temperature $m_{s} \cdot c_{s 2} \cdot t_{s 2}$.

For specific enthalpy of drying gas on input there is an equation:

$$
i_{1}=c_{p v} \cdot t_{1}+Y_{1}\left(r_{0}+c_{p v p} \cdot t_{1}\right) \quad\left[{\left.\mathrm{J} . \mathrm{kg}^{-1}\right]}^{-1}\right.
$$

where:

$c_{p v} \quad$ - middle mensural heat of gas $\left[\mathrm{J} \cdot \mathrm{kg}^{-1} \cdot \mathrm{K}^{-1}\right]$

$t_{1} \quad$ - temperature of drying gas on kiln input $\left[{ }^{\circ} \mathrm{C}\right]$

$Y_{1}$ - moisture of drying gas on input [ $\left.\mathrm{kg} \cdot \mathrm{kg}^{-1}\right]$

$r_{0} \quad$ - evaporative heat of water for temperature $0^{\circ} \mathrm{C} \quad\left[\mathrm{J}^{\mathrm{kg}} \mathrm{kg}^{-1}\right]$

$c_{p v p}$ - middle mensural heat of steam $\left[\mathrm{J} \mathrm{kg}^{-1} \cdot \mathrm{K}^{-1}\right]$

Similarly for specific enthalpy of drying gas on input, there is equation:

$$
i_{2}=c_{p v} \cdot t_{2}+Y_{2}\left(r_{0}+c_{p v p} \cdot t_{2}\right) \quad\left[\mathrm{J} \mathrm{kg}^{-1}\right]
$$

where:

$c_{p v} \quad$ - middle mensural heat of gas $\left[\mathrm{J} \mathrm{kg}^{-1} \cdot \mathrm{K}^{-1}\right]$

$t_{2}$ - temperature of drying gas on kilt output $\left[{ }^{\circ} \mathrm{C}\right]$

$Y_{2}$ - moisture of drying gas on output $\left[\mathrm{kg} \cdot \mathrm{kg}^{-1}\right]$

$r_{0} \quad$ - evaporation heat of water of temperature $0{ }^{\circ} \mathrm{C}\left[\mathrm{J}^{\mathrm{kg}} \mathrm{kg}^{-1}\right]$

$c_{p v p}$ - middle mensural heat of steam $\left[\mathrm{J} \mathrm{kg}^{-1} \cdot \mathrm{K}^{-1}\right]$

After substitution to the equation (1) we get following:

$$
\begin{array}{r}
\left\{m_{s p \cdot} \cdot\left[c_{p v} \cdot t_{1}+Y_{1}\left(r_{0}+c_{p v p} \cdot t_{1}\right)\right]\right\}+\dot{m}_{v 1} \cdot c_{v 1} \cdot t_{v 1}+\dot{m}_{s} \cdot c_{s 1} \cdot t_{s 1} \\
=\left\{m_{s p} \cdot\left[c_{p v} \cdot t_{2}+Y_{2}\left(r_{0}+c_{p v p} \cdot t_{2}\right)\right]\right\} \dot{m}_{s} \cdot c_{s 2} \cdot t_{s 2}
\end{array}
$$

Mass flow of water $\dot{m}_{v 1}$ can be expressed based on the equation

$$
m_{v 1}=\dot{m}_{s} \cdot u_{1} \quad\left[\mathrm{~kg} \cdot \mathrm{kg}^{-1}\right]
$$

where

$u_{1} \quad$ - mensural moisture $\left[\mathrm{kg} \cdot \mathrm{kg}^{-1}\right]$

$\dot{m}_{v 1}$ - mass flow of water on kilt input $\left[\mathrm{kg} . \mathrm{s}^{-1}\right]$

$\dot{m}_{s} \quad$ - mass flow of solid on kiln input $\quad\left[\mathrm{kg} . \mathrm{s}^{-1}\right]$
Mass flow of solid $\dot{m}_{s}$ can be expressed from equation

$$
\dot{m}_{s}=\frac{m_{v 2}}{u_{2}} \quad\left[\mathrm{~kg} \cdot \mathrm{kg}^{-1}\right]
$$

After substitution from equations (5) and (6) into equation (4) we get following:

$\left\{m_{s p} \cdot\left[c_{p v} \cdot t_{1}+Y_{1}\left(r_{0}+c_{p v p} \cdot t_{1}\right)\right]\right\}+\dot{m}_{s} \cdot u_{1} \cdot c_{v 1} \cdot t_{v 1}+$
$+\dot{m}_{s} \cdot c_{s 1} \cdot t_{s 1}\left\{m_{s p} \cdot\left[c_{p v} \cdot t_{3}+Y_{2}\left(r_{0}+c_{p v p} \cdot t_{2}\right)\right]\right\}+\frac{m_{v 2}}{u_{2}} \cdot c_{s 2} \cdot t_{s 2}$

From here the mensural moisture of granulate can be expressed $u_{2}$

$$
\begin{aligned}
& u_{2}=\frac{\dot{m}_{v 2} \cdot c_{s 2} \cdot t_{s 2}}{\left\{m_{s p} \cdot\left[c_{p v} \cdot t_{1}+\left(r_{0}+c_{p v p} \cdot t_{1}\right)\right]\right\}-\left\{m_{s p}^{*} \cdot\left[c_{p v} \cdot t_{2}+Y_{2}\left(r_{0}+c_{p v p} \cdot t_{2}\right)\right]\right\}+m_{s} \cdot u_{1} \cdot c_{v 1} \cdot t_{v 1}+\dot{m}_{s} \cdot c_{s 1} \cdot t_{s 2}} \\
& {\left[\mathrm{~kg}^{\mathrm{kg}} \mathrm{kg}^{-1}\right]}
\end{aligned}
$$

\section{CONCLUSION}

Goal of these studies was on the base of obtained experimental measurements and defined input and output parameters of drying to express dependency of moisture of ceramic granulate (u2) on moisture of output drying gas (Y2). It is nonlinear function, where course depends on values of all parameters in equation. Values of parameters are dependent on drying device. This dependency will be further used for verification in simulation model of drying process, which will allow affection of drying process on the base of parameters definition and thus to know how particular changes impact ceramic granulate itself.

As described technological process is very complex it is necessary to add more parameters to the dependency that are not yet in equation, such as thermal and material aspects of drying process. Aim of this study is to use that dependency for controlling of drying process.

Further experiments need to be realized based on requirements of this technological process.

\section{REFERENCES}

Dobransky, J; Hatala, M. (2007). Influence of selected technological parameter to quality parameters by injection molding. Annals of DAAAM for 2007 \& proceedings of the 18th International DAAAM Symposium., (Oct -2007). ISBN 3901509585

Orlovsky, I. (2008). Identification of thermal effects in production processes. Doctoral thesis, (2008), p.84, Faculty of Manufacturing Technologies of Technical University in Košice with seat in Prešov

Orlovsky, I.; Hatala, M. (2009). Sprinkle drying kiln ceramic granulate drying characteristic and experimental measurements of the drying process parameters. Technical Gazette, Vol. 16, No. 2 (april-jun 2009), p. 27-30, ISSN 1330-3651

Monka, P; Monkova, K. (2009). Basic mathematical principles for internal structure of new capp software. Annals of $D A A A M$ for 2009 \& proceedings of the $20^{\text {th }}$ international DAAAM symposium. Vol. :20, ISSN: 1726-9679, ISBN: 978-3-901509-70-4, pp. 1281-1282, Published: 2009, Vienna, Austria

Hloch, S; Valicek, J; Simkulet, V. (2009) Estimation of the smooth zone maximal depth at surfaces created by abrasive waterjet. International Journal of Surface Science and Engineering. - Vol. 3, No. 4, (2009), p. 347-359. ISSN 1749-785X

Orlovsky, I.; Hatala, M.; Janak, M. (2010). Creation of simulation model of ceramic granulate production in spraying kiln. Technical Gazette, Vol. 17, No. 4, (Dec 2010), p. 419-423, ISSN 1330-3651 